Изв. АН Эстонии. Геол., 1990, 39, № 2, 60-67.

УДК $553.983: 551.733(474.2)$

Велло КАТТАЙ

\title{
ЛОҚАЛЬНЫЕ ИЗМЕНЕНИЯ В СТРОЕНИИ ПРОМЫШЛЕННОЙ ПАЧКИ КУКЕРСИТОВ ЭСТОНСКОГО МЕСТОРОЖДЕНИЯ
}

Промышленная пачка горючего сланца кукерсита (промпачка) Эстонского месторождения (ЭМ) в пределах полей действующих шахт и карьеров и детально разведанных площадей для нового шахтного строительства на общей площади свыше 2 тыс. км ${ }^{2}$ четко расчленяется на восемь сланцевых слоев (снизу вверх $A, A^{\prime}, B, C, D, E, F_{1}, F_{2}$ ) и пять разделяющих их прослоев известняка $\left(A / A^{\prime}, A^{\prime} / B, B / C, C / D\right.$ и $\left.D / E\right)$.

Детальное изучение промпачки показывает высокую стабильность ее строения, выдержанность мощности и наличие постепенных и закономерных ее изменений от центра $Э М$ (район г. Кохтла-Ярве) к его периферийным частям (Каттай, 1981; Бауков и др., 1982; Аалоэ, 1983 и др.). Градиент уменьшения общей мощности промпачки в западном направлении составляет $1-3 \mathrm{~cm} / \mathrm{kм}$, на юг - 3-5 cм/км, т. е. в меридиональном направлении ее мощность уменьшается в два раза быстрее, чем в широтном.

Суммарная мощность сланцевых слоев промпачки имеет аналогичную закономерность в изменении. В то же время суммарная мощность известняковых прослоев имеет тенденцию возрастания с запада на восток от $0,45-0,50$ до $0,7-0,8$ м, градиент не превышает $0,2-0,3$ см/км, и в целом известняковые прослои являются более выдержанными, чем сланцевые слои. Ориентировка изопахит суммарной мощности известняков промпачки и мощности кукрузеского горизонта в определенной степени совпадают, чего нельзя сказать в отношении суммы сланцевых сіоев, поскольку факторы, благоприятствовавшие накоплению кукерситовых и карбонатных илов, различны (рис. 1).

Генетические факторы седиментации обусловили непрерывное рас-
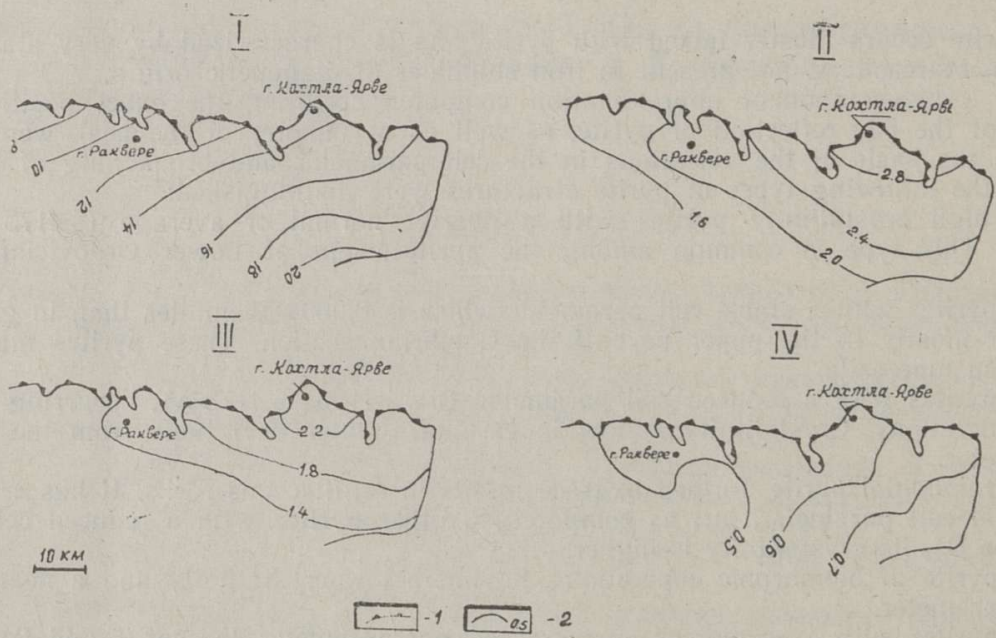

Рис. 1. Схема изменения мощности кукрузеского горизонта (I) и промышленной пачки кукерсита (II - общая мощность, III - суммарная мощность сланцевых слоев, IV суммарная мощность известняковых прослоев). 1 - эрознонная граница месторождения, 2 - изопахиты, м. 
пространение сланцевой залежи в пределах всего ЭМ - расщеплений, резких выклиниваний или значительных внутриформационных размывов не зафиксировано. Из вторичных, наложенных факторов, являющихся причинами резкого обрыва сплошности промпачки, являются эрозионные и карстовые процессы. Северная граница ЭМ в целом эрозионная, вблизи нее развиты дочетвертичные размывы залежи по эрозионным погребенным долинам. Локальные участки замещения промпачки карстовой глиной в зонах глубинного карста по площади не превышают на месторождении $1-2 \%$ (Каттай, 1986).

В литературе имеются отрывочные данные о наличии локальных изменений в строении средней части промпачки на разрабатываемой площади, связанных с уменьшениями мощности отдельных слоев, вплоть до их полного выклинивания, и резкими изменениями текстурных особенностей пород (Бауков, 1956; Насонова, 1962; Аалоэ, 1983). Данных о площадном развитии этого явления не приводится.

В 1978 г. при проходке подготовительных горных выработок в югозападной части шахтного поля Сомпа геолог шахты Е. Н. Лупанов зафиксировал также наличие локальных изменений в строении средней части промпачки. Он предположил, что промпачка «аномального» строения имеет развитие лишь на площади порядка $0,5 \mathrm{kм}^{2}$. Протяженность данного участка составляет примерно 1,3 км в субширотном направлении и ширина не более $0,3-0,5$ км (Лупанов, 1980).

Автор статьи поставил перед собой задачу обобщить имеющиеся данные, указывающие на наличие определенных локальных изменений в строении промпачки на ЭМ, определить конкретные площади их развития и выявить характер этих изменений.

По данным геологоразведки, участки с нетипичным строением средней части промпачки зафиксированы в районе действующих шахт Кохтла, Сомпа (в дальнейшем Сомпаский участок), а также на площади горных отводов карьеров Вийвиконна и Сиргала (Вийвиконнаский и Сиргалаский участки) (рис. 2.). Поскольку общая мощность промпачки на этих участках существенно не изменялась, считалось, что это явление имеет только локальное развитие и ему в период разведки не придавалось особого значения. Эксплуатационные данные и результаты непосредственного визуального обследования горных выработок подтверждают факт наличия промпачки с аномальным строением ее средней части (в дальнейшем «аномальная» промпачка) на указанных площадях. Имеется и целый ряд зарисовок, выполненных геологами шахт и карьеров ПО «Эстонсланец» Э. Эрисалу, А. Рохтлаан, Е. Лупановым, K. Сокманом и другими.

Геологические материалы эксплуатационных работ и первичные данные геологоразведки (после определенной их переинтерпретации) позволили отстроить серию геологических разрезов с детальным расчленением промпачки, откартировать площади распространения «аномальной» промпачки и получить в целом довольно полное представление о характере развития этого своеобразного явления на трех изолированных друг от друга участках $Э М$ (рис. 2,3$)$.

В настоящее время горноподготовительные выработки западного фланга шахты Сомпа и южного фланга шахты Кохтла вскрыли промпачку подобного строения на площади более 5 км²$^{2}$. На примыкающей с юго-запада к ним территории, по данным бурения, промпачка с «аномальным» строением фиксируется ориентировочно еще на площади более 13 км²$^{2}$. В плане контур участка имеет несколько овальную форму, протяженность его по длинной оси, ориентированной в северо-восточном направлении, составляет более 6 км, поперечные размеры - 2-4 км. В структурном отношении участок расположен в северном, поднятом крыле Ахтмеской зоны нарушений (рис. 2). 


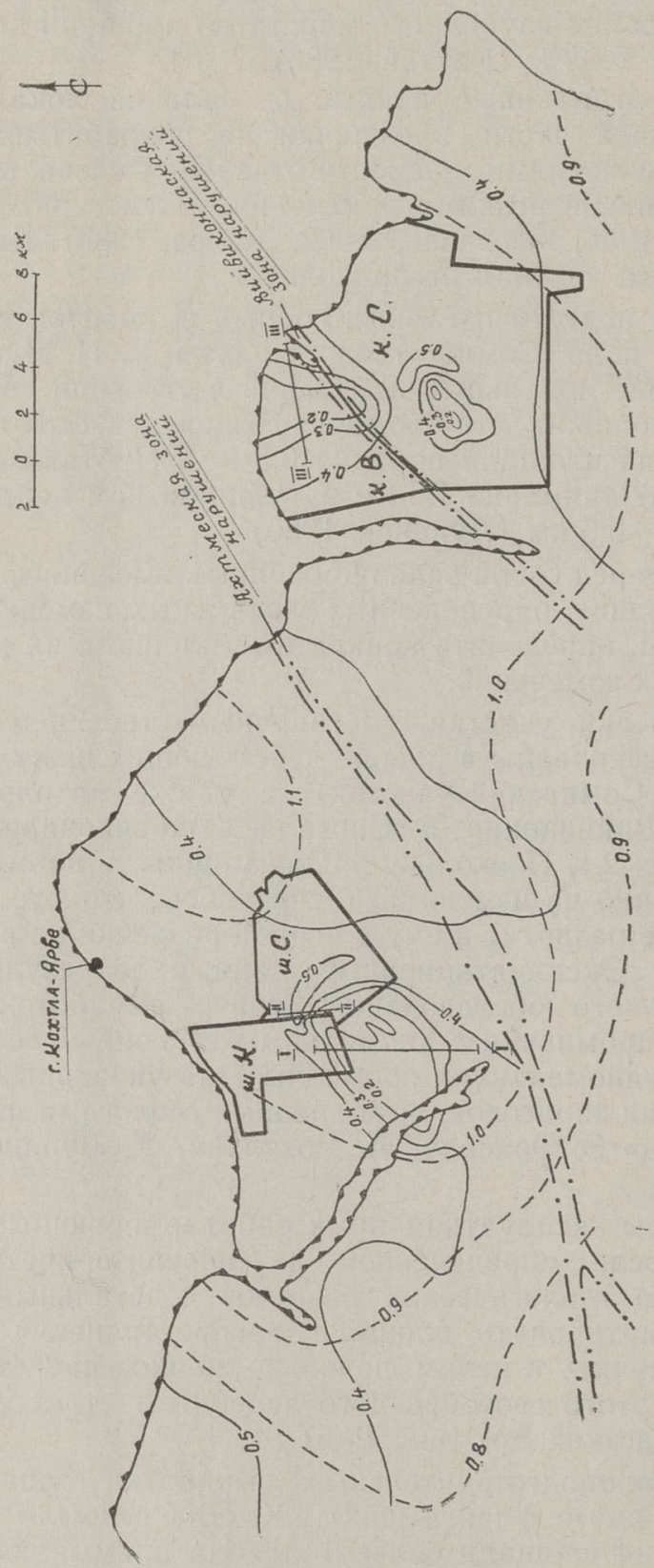

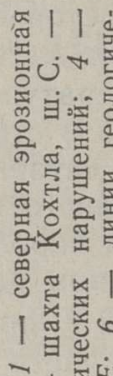

-1 볐어

i 닌 돋임

1

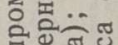
1

iู $\quad$ क्ष

i. 过

ह

i

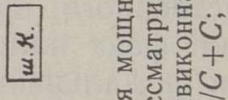

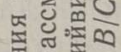

i 焉+

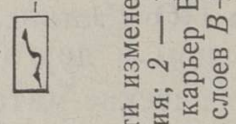

웡 I

현

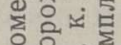

퐁헝

ले

๓

곯

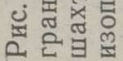


Вийвиконнаский участок с «аномальной» промпачкой расположен в 30 км восточнее первого и в настоящее время полностью отработан. Общая площадь его около $16 \mathrm{kм}^{2}$, большая часть приходится на карьер Вийвиконна (90\% площади) и лишь небольшая - на территорию карьера Сиргала, граница между которыми проходит по Вийвиконнаской зоне нарушений (рис. 2). Северная граница участка совпадает с эрозионной границей ЭМ, ширина его здесь наибольшая - до 4,5 км, постепенно сужается в южном направлении и в районе Вийвиконнаского нарушения составляет 2,5-3,0 км. Общая протяженность сохранившегося участка распространения «аномальной» промпачки с севера на юг около 5 км.

Сиргалаский участок расположен в $2-2,5$ км южнее Вийвиконнаского и непосредственно примыкает с запада к отработкам карьера Сиргала. По размерам третий участок значительно уступает первым двум. В плане он вытянут в северо-восточном направлении и имеет протяженность около 3,5 км, в поперечнике около 1 км, общая его площадь порядка $3,5-4 \mathrm{~km}^{2}$. Наличие «аномальной» промпачки зафиксировано по ограниченному количеству скважин.

Что касается изменений в строении промпачки на рассматриваемых участках, то по своему характеру они довольно однотипны и охватывают только ее среднюю часть от слоя $C$ до слоя $E$ (рис. 3 ). В слоях, залегающих выше и ниже, каких-либо изменений мощности, текстурных особенностей, состава и качества сланца не зафиксировано, поэтому они автором не рассматриваются.

Ниже дается послойная характеристика средней части «аномальной» промпачки снизу вверх на основании визуальных наблюдений.

Кукерситовый слой $C$. Мощность слоя $C$ в нормальном разрезе на территории рассматриваемых шахт и карьеров составляет в среднем $0,4-0,5$ м. В промпачке аномального строения мощность слоя, как правило, увеличена до $0,6-0,7$ м, а местами, на Вийвиконнаском участке, достигает $0,8-1,0$ м, что в общем является максимальным в целом для ЭМ. Поскольку данные о мощности этого слоя иногда могут быть искажены из-за неоднозначного разделения слоев $B$ и $C$, целесообразнее рассматривать суммарную мощность этих слоев вместе с разделяющим прослоем $B / C$. Мощность слоев $B+C$ в «аномальной» промпачке состав ляет $1,2-1,6$ м, а по отдельным точкам на Вийвиконнаском участке до $1,7-1,8$ м, при фоновой в нормальном разрезе - $0,9-1,1$ м (рис. 2, 3).

Как правило, верхняя часть слоя $C$ мощностью $0,1-0,35$ м интенсивно проработана илоедами, ходы которых заполнены известковым материалом. Следует отметить, что наличие их в слое $C$ в общем-то характерно для всего ЭМ, однако мощность биотурбированной части слоя обычно составляет несколько сантиметров и не превышает $5-7$ см. Ходы илоедов пронизывают как кукерсит, так и включения известняка, если те расположены именно в верхней части слоя (таблица). Расположены ходы илоедов чаще горизонтально и слабонаклонно, по форме они округлые или слегка сплюснутые по напластованию пород, диаметр в основном $2-5$ мм, изредка крупнее - до 1 см. В вертикальном сечении пород они занимают по площади до $20-40 \%$ и редко больше (таблица). Ходы имеют резкие контуры и на фоне светло-коричневого кукерсита и кремового керогенсодержащего известняка включений четко выделяются светло-серой окраской с синеватым оттенком. Визуально известняк, заполняющий ходы, содержит незначительное количество керогена и по составу схож с составом прослоя $C / D$.

В результате деятельности илороющих организмов в верхней части слоя $C$ нарушена первично-седиментационная горизонтально-слонстая текстура осадка и на ее месте образовалась вторичная, биотурбацион- 
ная (Аалоэ, 1983). Однако между ходами просматривается следующее: кукерсит как в верхней, так и в нижней части массы слоя имеет горизонтально-слоистую текстуру, т.е. спокойная обстановка седиментации сохраняется. Форма и резкие границы ходов роющих организмов указывают на то, что их жизнедеятельность происходила в уплотненном или даже в литифицированном осадке.

В горной практике ЭM интервал верхней части слоя $C$ с ходами илоедов получил название «лошадиной кожи». Поскольку этот интервал имеет мощность в «аномальной» промпачке до $30-35$ см, но резко отличается по составу и качеству, в дальнейшем при документации и опробовании горных выработок и скважин целесообразно его выделять как самостоятельный слой, присвоив ему, например, индекс ЛК (рис. 4).

Известняковый прослой $C / D$ («двойная плита») в составе промпачки в пределах ЭМ в региональном плане является наиболее выдержанным по мощности и составу. От других прослоев отличается стабильной светло-серой окраской с синеватым оттенком, более чистым составом (глинистость до 10-12\% и содержание керогена до $2-3 \%$ ), поэтому при расчленении и корреляции слоев промпачки, интерпретации каротажных диаграмм он используется как маркирующий слой.

По устным данным X. Бауэрта, прослой четко прослеживается до западного побережья материковой части Әстонии на протяжении более 300 км, мощность его варьирует в основном в пределах $15-35$ см. Для сравнения отметим, что в сумме сланцевые слои $B+{ }^{\circ} C$ (максимальная мощность в районе Кохтла-Ярве 1,2-1,8 м) западнее Раквере имеют мощность уже менее $0,5-0,4$ м и расчленить их не всегда удается.

В «аномальной» промпачке на рассматриваемых участках прослой $C / D$ неузнаваем. Во-первых, мощность его в основном составляет до $10-15$ см против фоновой 25-35 см. Во-вторых, он может состоять из двух разных по облику (цвет, текстура) и составу прослоев, разделенных четко выраженной пиритизированной поверхностью перерыва (ППП), или одного прослоя. В последнем случае он представлен кремовым керогеновым известняком (керогена 7-10\%) с многочисленными разноориентированными ходами илоедов, составляющими до $20-30 \%$ породы и заполненными светло-серым известняком, визуально аналогичным собственно прослою $C / D$. Насыщение керогеном неравномерное. На карьере Вийвиконна в прослое $C / D$ отмечены даже тонкие прослойки (несколько мм) кукерсита. Для прослоя характерно также наличие серых пятен, разводов пиритизации. Верхняя граница его неровная, изрезанная и проходит по ППП. Иногда их может быть в слое несколько, но все они, кроме верхней, как правило, невыдержаны по простиранию. Распределение пиритовой импрегнации неравномерное. Мощность темно-серой ее полосы на Сомпаском участке в основном несколько миллиметров и не превышает 2-3 см, на Вийвиконнаском больше, местами может достигать 3-5 см и окраска выражена интенсивнее (таблица)

По классификации Р. Эйнасто (1964), ППП неровная, сглаженная, местами несглаженная. Глубина карманов незначительная - преимущественно до 2-3 см, редко до 5-7 см. Заполнены они известняком или кукерситом, в зависимости от того, какой слой лежит на ППП.

В тех случаях, когда прослой $C / D$ как бы раздвоен, нижняя часть его представлена описанным выше керогеновым известняком, а верхняя, расположенная выше ППП, - светло-серым известняком с низким содержанием керогена, без ходов илоедов, т.е. таким, каким является прослой $C / D$ в нормальном разрезе.

Можно предположить, что эти локальные участки развития $C / D$ при седиментации являлись зонами отмелей с сильно подвижной водной средой. Образование выдержанных ППП в кровле слоя $C / D$ происхо- 
ТАБЛИЦА
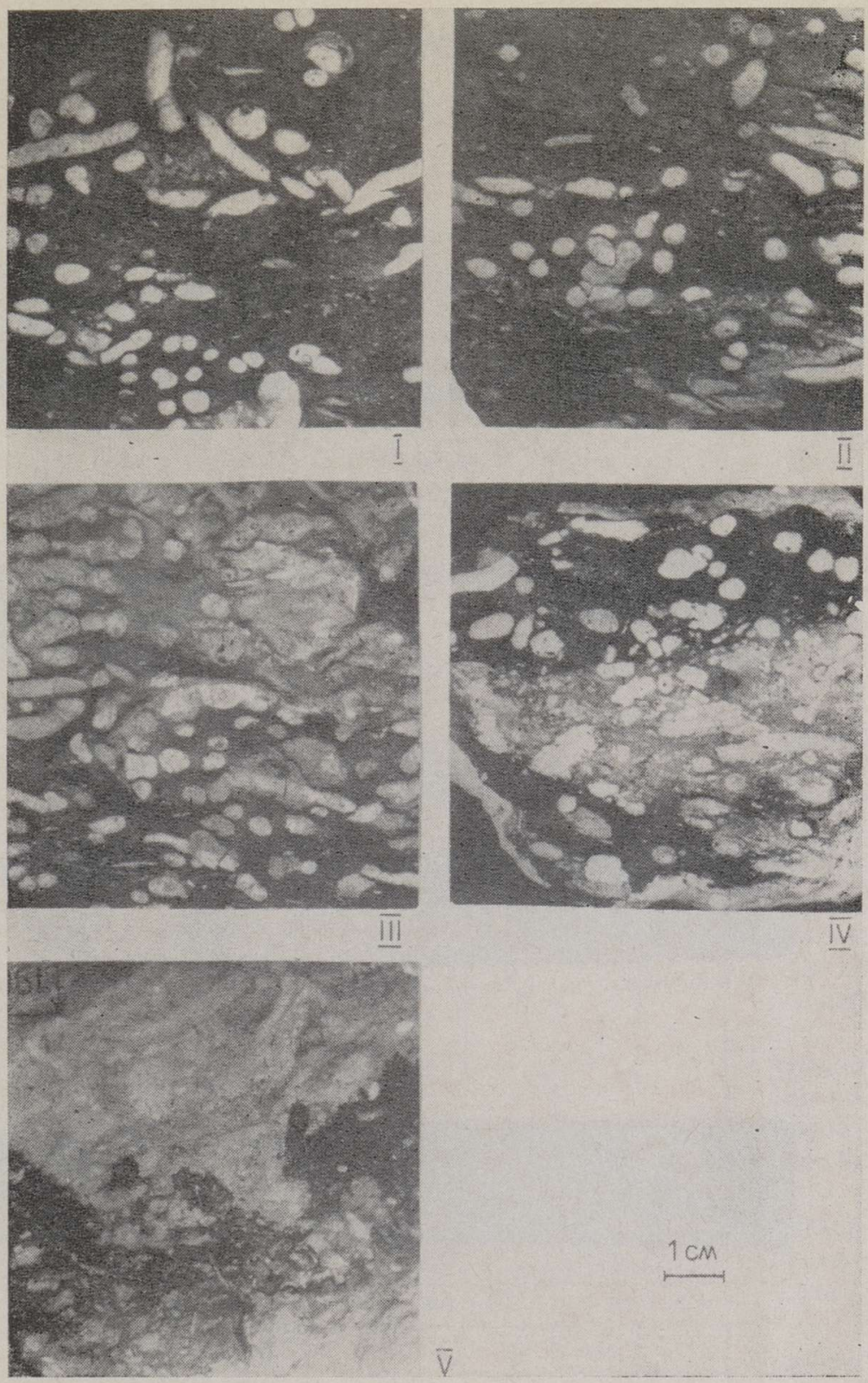

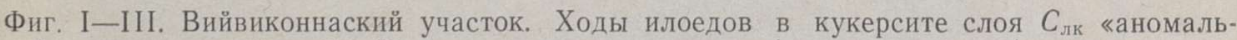
ной» промпачки. Фиг. IV. Ходы илоедов в кукерсите (темно-серый тон) и включениях известняка (светло-серый тон) слоя $C_{\text {лк. }}$ Фиг. V. Пиритизированная поверхность перерыва на границе прослоев $C / D_{\text {л }}$ и $D / E$. 


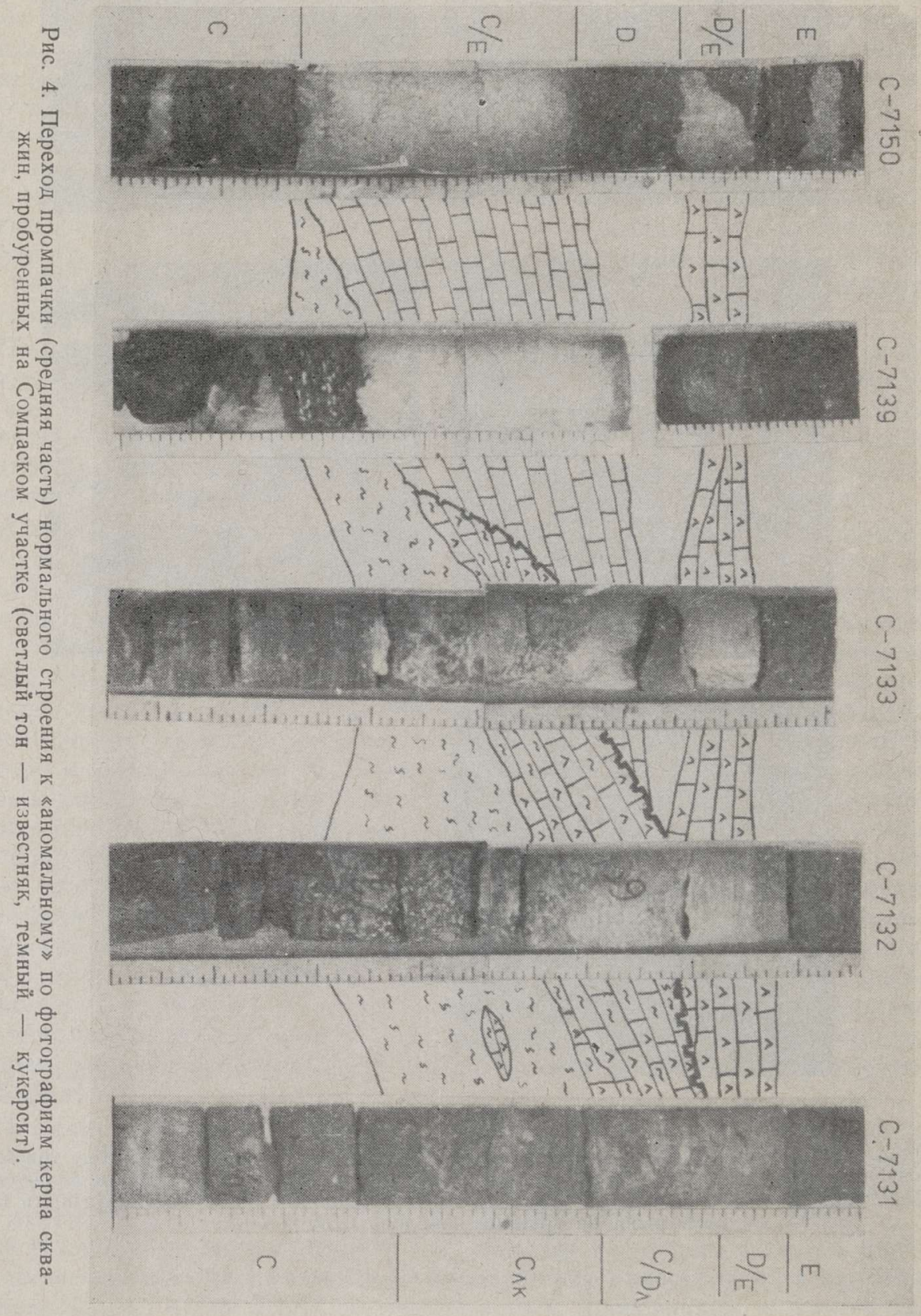




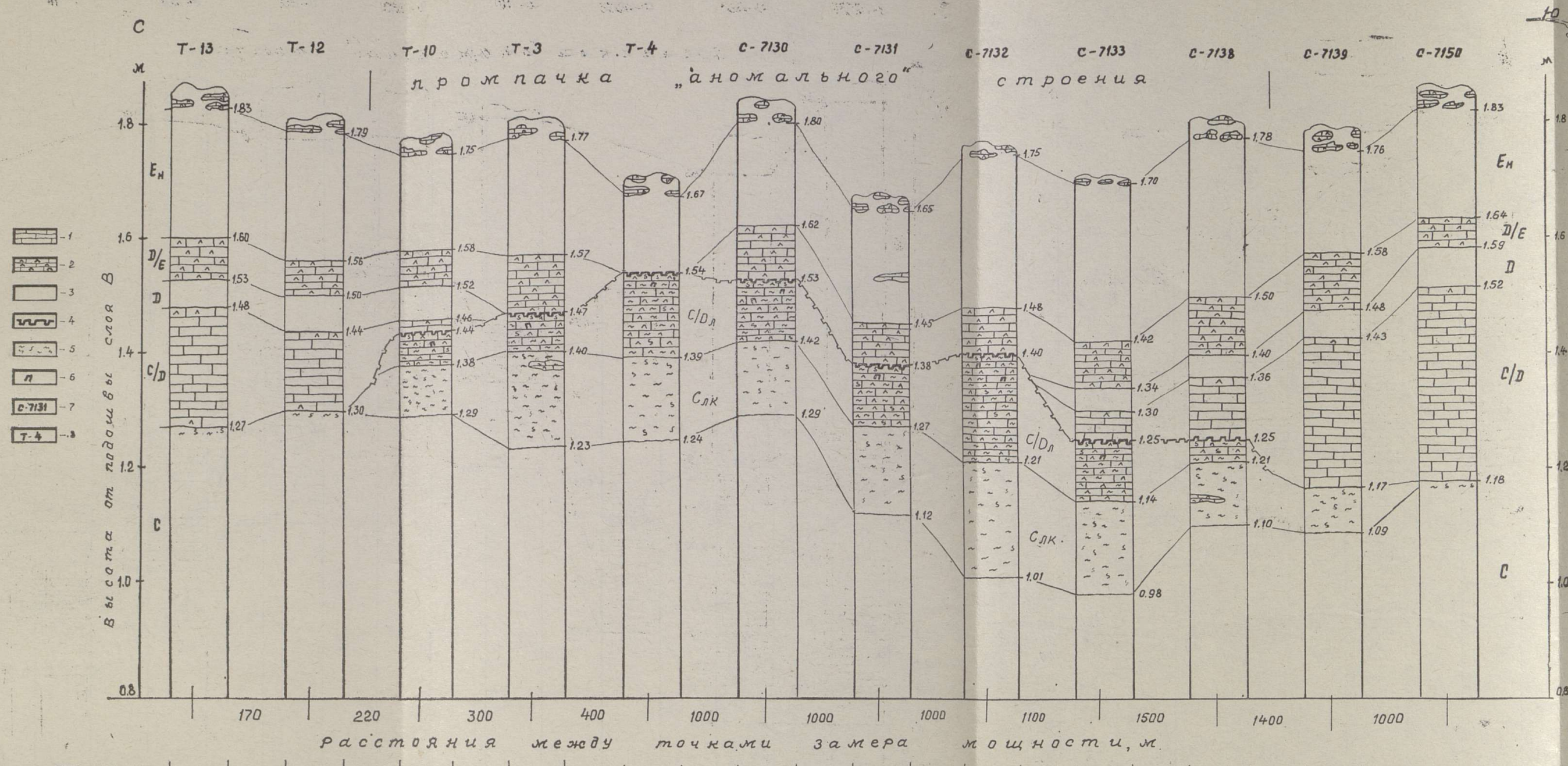

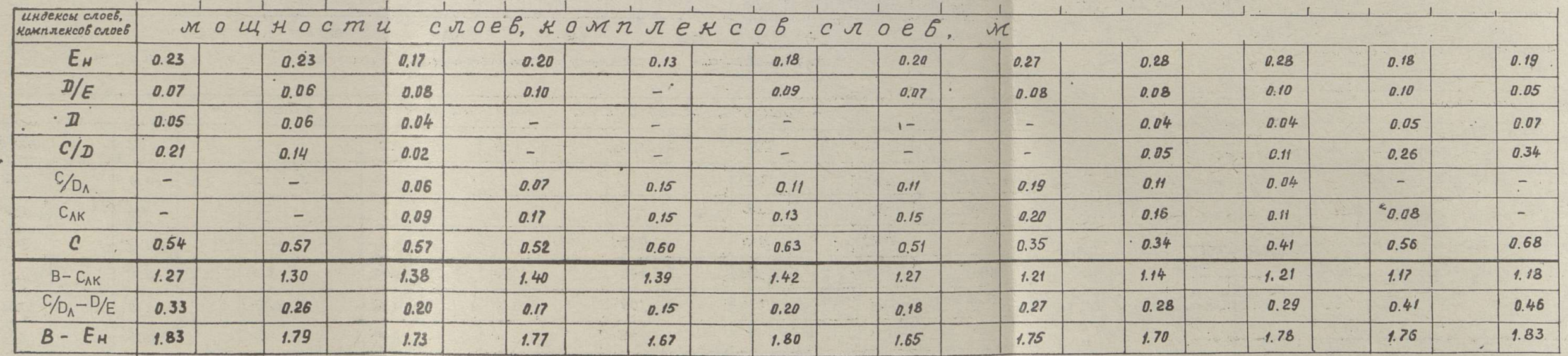

Рис. 3. Строение средней части промышленной пачки по линиям геологических разрезов I-I, II-II (Сомпаский участок), III-III (Вийвиконнаский участок). 1 - известняк; 2 - керогеновый известняк; 3 - кукерсит; 4 -пиритизированная поверхность перерыва; 5 - ходы илоедов; 6 - пиритовые узоры, пятна; $7-$ скважина, ее номер; $8-$ точка замера мощности в шахтах 

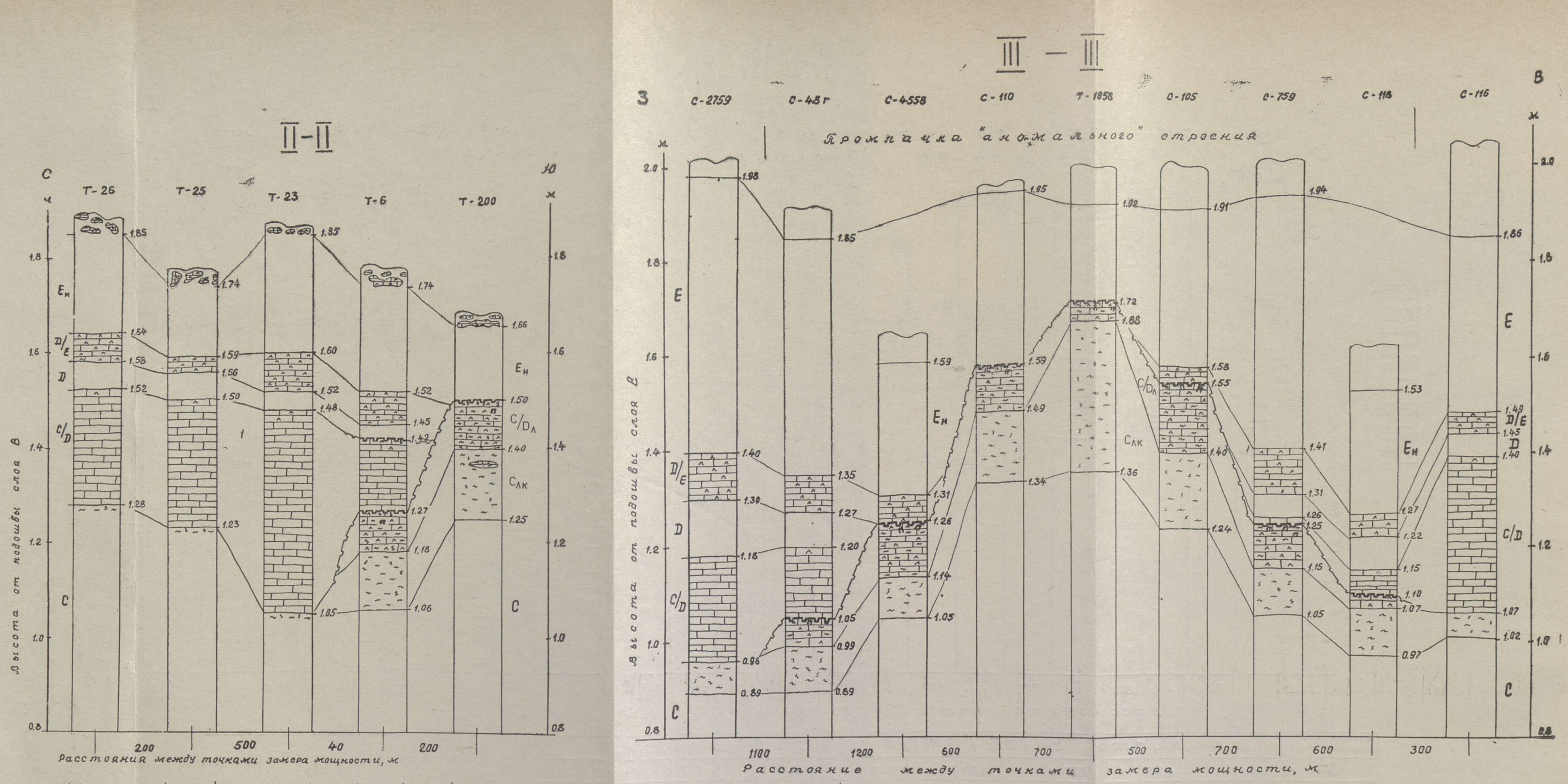

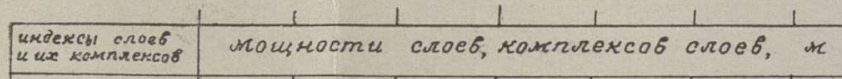

\begin{tabular}{|c|c|c|c|c|c|c|c|c|c|}
\hline$E_{H}$ & 0.21 & & 0.15 & & 0.25 & & 0.22 & & 0.16 \\
\hline$D / E$ & 0.06 & & 0.03 & & 0.08 & & 0.07 & & - \\
\hline$D$ & 0.06 & & 0.06 & & 0.04 & & 0.03 & & - \\
\hline$C / D$ & 0.24 & & 0.27 & & 0.43 & & 0.15 & & - \\
\hline$C / D_{\Lambda}$ & - & & - & & - & & 0.09 & & 0.10 \\
\hline$C_{A K}$ & - & & - & & - & & 0.12 & & 0.15 \\
\hline$C$ & 0.58 & & 0.52 & & 0.35 & & 0.31 & 0.47 \\
\hline$B-C_{A K}$ & 1.28 & & 1.23 & & 1.05 & & 1.18 & \\
\hline$C / D_{\Lambda}-D / E$ & 0.36 & 0.36 & & 0.55 & & 0.34 & & 0.10 \\
\hline$B-E_{H}$ & 1.85 & & 1.74 & & 1.85 & & 1.74 & & 1.66 \\
\hline
\end{tabular}

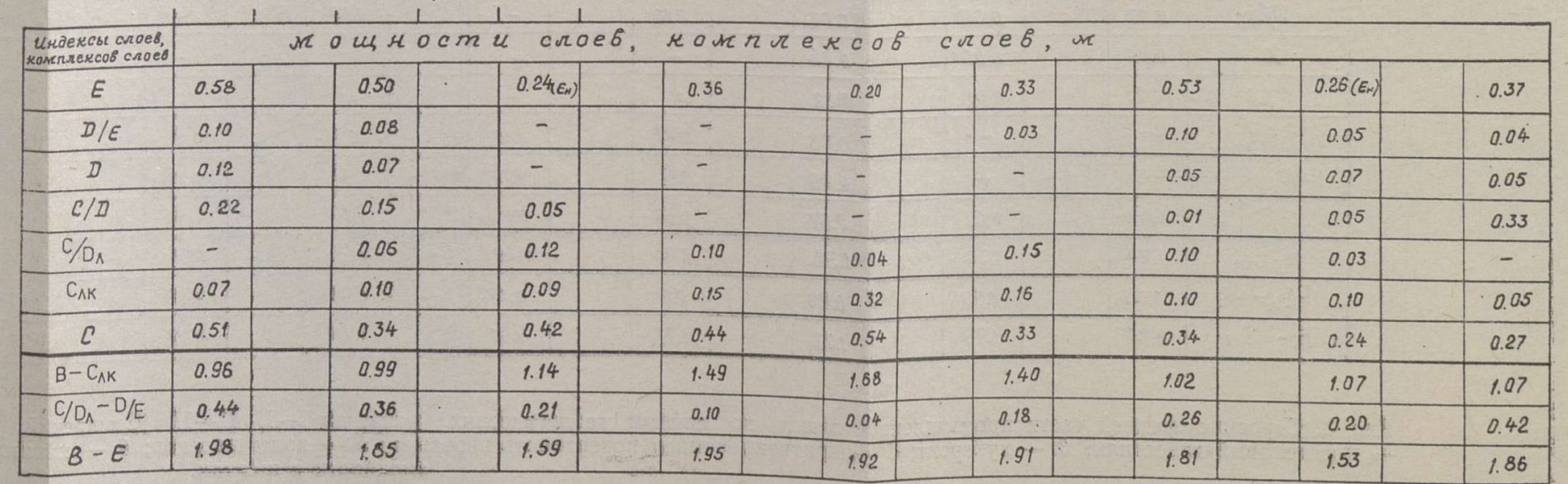


u $E$;

- выклинивание слоев $C / D, D$, а на отдельных участках также $D / E$

- появление в разрезе прослоя керогенового известняка $\left(C / D_{\text {л }}\right)$, не имеющего себе аналогов в промпачке;

- увеличенная мощность слоя $C$ и появление прослоя $C / D_{\text {л }}$ в значительной мере компенсируют выклинивание слоев $C / D, D, D / E, E$ и поэтому «аномальная» промпачка существенно не отличается по мощности от нормального ее разреза (разница до $0,15-0,25 \mathrm{~m}$ ).

До сих пор исследований с целью расшифровки условий седиментации, приведших к образованию локальных участков с «аномальным» строением средней части промпачки, не проводилось.

C. С. Бауков (1956) объясняет «выпадение» из разреза прослоя $C / D$ эпигенетическим размывом на границе слоев $C / D$ и $D$. H. M. Насонова (1962) отмечает, что размыву в этом случае подверглись также вышележащие слои $D$ и $D / E$. Е. Н. Лупанов (1980) считает, что это может быть результатом локального перераспределения осадочного материала. А. Р. Аалоэ (1983) высказывает предположение о том, что эти участки могли быть локальными поднятиями дна бассейна с предельно сокращенной седиментацией.

Автор пытается трактовать образование «аномальной» промпачки, исходя из особенностей ее послойного строения, как следствие наличия локальных участков, где существовали условия для усиленной седиментации в период отложения кукерситообразующих илов слоя $C$ с последуюшим замедлением темпа осадконакопления (прослой $C / D_{\text {л }}$ ) и временным ее прекращением (слой $D$, а местами также $D / E$ и $E$ ).

Безусловно, вопрос природы «аномальной» промпачки сложный и требует проведения специальных исследований. Можно надеяться, что Сомпаский участок с его доступными и хорошо прослеживаемыми обнажениями по стенкам горных выработок привлечет к этому вопросу внимание литологов, петрографов, палеонтологов и других специалистов, занимающихся проблемами седиментологии и генезиса горючих сланцев, поскольку, не исключено, это может стать «ключом»к расшифровке некоторых неясных вопросов кукерситонакопления в целом.

В заключение следует сказать, что изучение подобных участков имеет не только чисто теоретическое, но и прикладное значение, поскольку с ними связаны изменения мощности слоев, качества сланца, состава и физико-механических свойств пород.

В настояшее время на шахтах Кохтла и Сомпа, не имеющих обогатительных фабрик, очистные работы производятся с применением комбайновой выемки только нижней части промпачки (слои $A-C$ ). Эксплуатационные потери при этом достигают порядка $45-50 \%$, так как в недрах остается вся верхняя часть залежи. Одной из причин применения технологии неполной выемки промпачки является высокая для режущего инструмента комбайнов прочность известняков прослоя $C / D$.

Как показывают визуальные наблюдения, на участках с аномальным

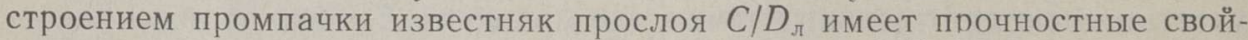
ства несравненно ниже и мощность меньше, чем $C / D$. Поэтому, с точки зрения рационального использования сланцевых ресурсов ЭМ, вопрос о возможности и целесообразности ведения комбайновой выемки на полную мощность промпачки в пределах не отработанных еще площадей шахт Қохтла и Сомпа и примыкающей к ним с юга-запада территории несомненно заслуживает дальнейшего изучения (Каттай, Юргенфельдт, 1989).

При открытых горных работах на карьере Сиргала промпачка аномального строения может быть отработана одним рабочим vступом, поскольку породный уступ, вынимаюший слои $C / D-D-D / E$, исключа ется из-за незначительной мощности этого комплекса слоев, 
Аалоэ А. Р. Закономерности строения промышленной пачки кукерсита Прибалтийского бассейна и некоторые вопросы кукерситонакопления // Деп. ВИНИТИ, № 600-3-83, 1983.

Бауков С. С. Тектонические условия сланщенакопления !/ Тр. ИГ АН ЭССР, 1956, 1, 95-104.

Бауков С., Морозов О., Тубли T. Закономерности изменения основных параметров промышленной пачки горючего сланца Эстонского месторождения // Изв. $\Lambda \mathrm{H}$ ЭССР. Геол., 1982, 31, № 4, 140-145.

Геккер Р. Ф. Ископаемая фация гладкого каменного морского дна // Тр. ИГ АН ЭССР, 1960, V, 199-227.

Каттай B. А. Карстовые нарушения в промышленной залежи Әстонского месторождения кукерситов и закономерности их проявления // Горючие сланцы, 1986, 3, № 3, 225-233.

Каттай $B$. A. Общие закономерности изменения основных параметров промышленного пласта сланца Эстонского месторождения // Вопросы геолого-маркшейдерской службы на сланцевых шахтах. Таллинн, 1981, 3-13.

Каттай B. А., Юргенфельдт $Г$. Ю. Геологические предпосылки снижения потерь при комбайновой выемке промышленной пачки сланца на полях шахт Сомпа и Кохтла // Сланцевая промышленность, 1989, № 1, 1-4.

Лупанов E. H. Двойная плита промпласта юго-западной части шахтного поля Сомпа // Инф. сер. 1. Горючие сланцы, 1980, № 8, 1-5.

Насонова Н. М. Структурно-текстурные особенности пород промышленного пласта Әстонского месторождения горючих сланцев // Тр. ИГ АН ЭССР, 1962, Х, 205-214.

Пылма Л. Сравнительная литология карбонатных пород ордовика северной и средней Прибалтики. Таллинн, 1982.

Эйнасто Р. Э. K вопросу классификации и формирования поверхностей перерыва // Литология палеозойских отложений Эстонии. Таллинн, 1964, 123-131.

Ннститут геологии

Академии наук Эстонской ССР
Поступила в редакцию

$12 / \mathrm{X}^{\prime} 1988$

\section{Vello KATTAI}

\section{LOKAALSED MUUTUSED EESTI KUKERSIIDIMAARDLA TOOTSA KIHINDI EHITUSES}

Geoloogiliste uurimistööde materjalid, samuti ekspluatatsiooni andmete üldistamine ja analüüs võimaldasid nii Sompa ja Kohtla kaevanduses kui ka Viivikonna ja Sirgala karjääri tehnilistes piirides välja eraldada kolm piirkonda (pindala $4-18 \mathrm{~km}^{2}$ ), kus pőlevkivi tootsa kihindi keskosa ehitus on ebatüüpiline. See väljendub eelkõige kukersiidi ja lubjakivikihtide suuremas muutlikkuses, kohati osade täielikus väljakiildumises. Pealegi toimuvad märgatavad muutused kivimi koostises, tekstuuris ja mehaanilistes omadustes. Selliste piirkondade uurimise ja väljaselgitamisega kaasneb lisaks puhtteaduslikule informatsioonile settimistingimustest ka oluline praktiline moment. Neil aladel on erinevalt ülejäänuist võimalik kasutada tunduvalt ratsionaalsemat tootmistehnoloogiat tööstusliku kihindi lausväljastamist.

\section{Vello KATTAI}

\section{LOCAL STRUCTURE CHANGES IN THE COMMERCIAL SEAM OF THE ESTONIAN OIL-SHALE KUKERSITE DEPOSIT}

Generalization and analysis of the results of geological studies as well as the exploitation data allowed us to distinguish 3 regions (with the area from 4 to $18 \mathrm{~km}^{2}$ ) in the Sompa and Kohtla mines and Viivikonna and Sirgala open-cast pits, with the untypical structure of the central part of the commercial seam. First of all, this is expressed by greatly varying thickness of kukersite and limestone beds up to complete thinning out and sharp changes in the composition, texture and mechanical characteristics of the rock. The study of such areas is important not only from the purely scientific viewpoint, but it has also a considerable practical significance. Unlike in other regions, here it is possible to use a noticeably more rational mining technology - gross excavation of the commercial seam. 